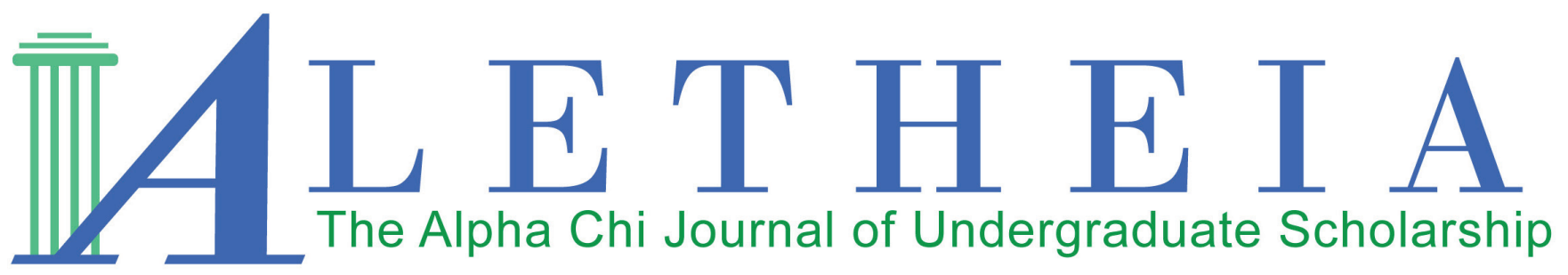

Volume 2 | Issue 1 | 2017

\title{
Greedy Like Gollum: Middle-earth According to Marx
}

\author{
Valerie Kocsis \\ Abilene Christian University \\ Texas Psi Chapter
}

Vol. 2(1), 2017

Article Title: Greedy Like Gollum: Middle-earth According to Marx

DOI: $10.21081 / \mathrm{AX} 0103$

ISSN: 2381-800X

Key Words: Tolkien, Middle-earth, Marx, capitalism, avarice, historical materialism, The Lord of the Rings This work is licensed under a Creative Commons Attribution 4.0 International License.

Author contact information is available from the Editor at editor@alphachihonor.org.

\section{Aletheia-The Alpha Chi Journal of Undergraduate Scholarship}

- This publication is an online, peer-reviewed, interdisciplinary undergraduate journal, whose mission is to promote high quality research and scholarship among undergraduates by showcasing exemplary work.

- Submissions can be in any basic or applied field of study, including the physical and life sciences, the social sciences, the humanities, education, engineering, and the arts.

- Publication in Aletheia will recognize students who excel academically and foster mentor/mentee relationships between faculty and students.

- In keeping with the strong tradition of student involvement in all levels of Alpha Chi, the journal will also provide a forum for students to become actively involved in the writing, peer review, and publication process.

- More information and instructions for authors is available under the publications tab at www.AlphaChiHonor.org. Questions to the editor may be directed to editor@alphachihonor.org.

\footnotetext{
Alpha Chi is a national college honor society that admits students from all academic disciplines, with membership limited to the top 10 percent of an institution's juniors, seniors, and graduate students. Invitation to membership comes only through an institutional chapter. A college seeking a chapter must grant baccalaureate degrees and be regionally accredited. Some 300 chapters, located in almost every state, induct approximately 12,000 members annually. Alpha Chi members have been "making scholarship effective for good" since 1922.
} 


\title{
Greedy Like Gollum: Middle-earth According to Marx
}

\author{
Valerie Kocsis \\ Abilene Christian University \\ Texas Psi Chapter
}

\begin{abstract}
The Ring in J. R. R. Tolkien's The Lord of the Rings trilogy is the most important material object in the realm of Middle-earth. As such, the Ring (and the power with which it imbues its owner) invites comparisons to capitalism in the modern world. The purpose of this paper is to view Tolkien's Ring through a Marxist lens. In such a reading, the Ring represents class divisions and hierarchies, the effects of greed and materialism, and the dehumanization of the greedy, all of which are themes that Karl Marx decries in reference to capitalism. This paper summarizes and examines the claims that Marx presents regarding capitalism, class structure, greed, and labor, and how these themes appear in Tolkien's The Lord of the Rings. It also considers the notion of historical materialism, through which Marx would suggest that greed in Middle-earth is primarily the result of external factors, exacerbated in the individual by possession of the Ring, rather than by some inherent character flaw.

The one Ring appears in Middle-earth as the ultimate fetishized commodity, the representation and manifestation of capitalism - of the good aspects of capitalism and of its evils as well. Greed for the Ring, however, is greed for power, not for money as in a strictly capitalist system. Nevertheless, the theme that undergirds both Marx and Tolkien is the reduction of the greedy into something less than human, leading ultimately to their destruction and downfall.
\end{abstract}

Key words: Tolkien, Middle-earth, Marx, capitalism, avarice, historical materialism, The Lord of the Rings

In the foreword to the second edition of The Lord of the Rings, J. R. R. Tolkien famously states his disdain for allegorical literature and his refusal to employ allegory in his own stories. He writes, "I cordially dislike allegory in all its manifestations, and always have done so" (xxiv). Therefore, any attempt to imbue his three-volume The Lord of the Rings work with meanings that parallel society (either in Tolkien's time or our own) must be done with great caution. Jay W. Richards helpfully notes, however, a clarification that Tolkien himself made: while his stories are not allegory, they do have applicability (Theology). As a work of literature that focuses especially on the material world - that is, on the one Ring of power-The Lord of the Rings invites a Marxist critique of the ways in which avarice, possession, and wealth-based power structures are both the causes and the manifestations of evil. In response to Karl Marx's criticism of the modern capitalist system, Ishay Landa writes, "I do not claim that in the Ring Tolkien created an allegory of capitalism, even unconsciously: it would be closer to say, however poetically, that the Ring is capitalism, mythically grasped" (124). The Ring is not an allegory for capitalism; rather, the Ring has applicability as a similar societal force to capitalism, with similar effects on the people in society. As the single material object prized above all others in Middle-earth, Tolkien's Ring is a representation of class conflict and hierarchical power structures, of material- 
ism and the culture of commodities and private property, and of the destructive effects of greed and capitalism on individuals.

Marx's concerns hinge upon the concepts of wealth, production, materialism, avarice, and the subsequent destruction of the greedy. These themes are abundantly apparent in Tolkien's The Lord of the Rings. However, in order to analyze them, one must first consider Tolkien's personal biases and the ways they are reflected in the story. Tolkien himself fought in the British Army during World War I, an experience that fomented in him strong disillusionment with violence, modernization, industrialization, and materialism. In a charming anecdote from Tolkien's life that speaks to his disdain for materialism and industrialization, the professor sold his family's first car shortly after purchasing it, in favor of biking around Oxford, lamenting to his son Christopher, "How I wish the 'infernal combustion' engine had never been invented" ("The Letters" 77).

Tolkien was a devout and conservative Catholic, quite unlike the communist Marx. Perhaps as a result of his beliefs, in The Lord of the Rings, Tolkien shows himself to be an advocate of class division and social hierarchy as being "good and ordained by God" (qtd. in Higham 68). Steve Higham points out the strict stratification of Tolkien's created world: the social structure of Middle-earth consists of powerful kings and lords on the top and soldiers on the bottom. High elves speak the ceremonial Quenya language, while lower elves speak Sindarin (207). In the appendix to The Lord of the Rings, Tolkien makes the distinction between Elven languages clear: Quenya, or "High-Elven," he writes, "had become, as it were, an 'Elven-latin', still used for ceremony, and for high matters of lore and song, by the High Elves." By contrast, Sindarin, spoken among the Grey-elves, was adopted "for daily use" (1128). Just as the Latin of the Catholic Church has historically lent hierarchical power to its speakers, Tolkien seems to suggest that this E1ven-Latin establishes hegemony over the speakers of a common vernacular.

While Tolkien imbued his created universe with hierarchical structures and strong central powers, it is important to note, as Richards points out, that he was not an advocate for any sort of Marxist revolution: "Tolkien was extremely skeptical of the use of centralized coercive power of centralized government, even for laudable goals" (Theology). Although the ends of communism might have appealed to Tolkien, they likely would not have justified the means - that is, the strong central government required to institute wealth redistribution. Yet because Tolkien was opposed to both materialism and communism, "His stories dialectically oscillate between a utopian renunciation of private property and its ideological vindication" (Landa 117). When considering Tolkien's portrayal of Middle-earth, we must therefore view him through the lens of anti-materialism, not pro-Marxism.

Such considerations of Tolkien's circumstances and convictions are necessary because of Marx's notion of historical materialism - the idea that "life is not determined by consciousness, but consciousness by life" (Marx and Engels 656). Marx emphasizes his theory that an individual believes what he believes only because of his societal (and especially his economic) position in life. John Nebauer points out that Tolkien's "childhood alternated between a countryside increasingly encroached upon by industrialisation, and the packed, soot encrusted buildings of Birmingham. His hobbits and their rustic land of the Shire were an idealised rural, parochial England, ruled in the end by a wise and benevolent king." Implicit in this claim is the idea that Tolkien wrote the way he wrote and believed the things he believed because of his economic and historical circumstances.

This existence of historical materialism is the central claim in Higham's Marxist analysis of The Lord of the Rings. In his ardent Catholicism, Tolkien would likely disagree with Marx's concept that one's circumstances determine his consciousness: "His religious outlook challenges the kernel of historical materialism which, as indicated above, argues that man, not God makes his own history" (Higham 38). Higham notes further that Tolkien was raised in an upper-middle class family, was well educated, and witnessed great class antagonismssuch as labor strikes for minimum wages, the fall of the aristocracy, and growing trade unions - during his formative years, and that these circumstances greatly shaped his views and his storytelling.

Indeed, much of what Tolkien wrote stands in opposition to the world in which he lived. To this end, Carl Freedman suggests, "Through three thick volumes, there is . . hardly a single important instance of . . class conflict," with the most obvious class division that between Frodo and his faithful sidekick Samwise (263). However, this claim requires clarification and even refutation: Tolkien may have created his idealized 
Middle-earth in The Fellowship of the Ring - the first volume of his work - and even in his earlier work, The Hobbit, as an effort to counteract the class strife and upheaval he saw in the real world throughout his lifetime. Ultimately, however, class conflict does occur in Middle-earth: those who do not have power overthrow the regime of those who do by destroying the Ring. Regardless, having grown up in a society of great class conflict and upheaval by the lower classes, it seems likely that Tolkien's literature is a response to these forces and events. Any portrayal of social structure, class division, and power in The Lord of the Rings is, Marx would argue, the direct result of the author's life circumstances shaping his consciousness.

Marx's concerns include the strict division between the bourgeoisie and proletariat in the capitalist system, particularly the way this system leads to greed and materialism, and the way these attitudes lead to the dehumanization of the laborer. In describing the polarization of the economy, Marx writes, "The necessary result of competition is the accumulation of capital in a few hands ... and that the whole of society must fall apart into the two classes - the property-owners and the propertyless workers" (652). ${ }^{1}$ Class is defined solely on the basis of material property - the haves and have-nots. In The Lord of the Rings, the Ring is a very tangible expression of immense power, reinforcing and intensifying the hierarchy and class division in Middle-earth. The economic polarization between the bourgeoisie and proletariat that Marx laments does exist in Middle-earth, between those who have power through the Rings and those who do not.

In the same way that Marx calls for a revolution from the lower, oppressed class, "Tolkien demonstrates ... that any sort of collaboration with the Powers - even with the means by which the Powers act-results in oppression. Only the use of the tools of the weak results in successful resistance to oppression" (Jeffers 12). Power is contained in the twenty Rings of Middle-earth, and

$1 \quad$ With the exception of The Communist Manifesto, quotations in this paper by Karl Marx and Friedrich Engels are taken from The Norton Anthology of Literary Theory and Criticism, vol. 2. The quotations come from excerpts of various essays; however, in each parenthetical citation, they will be labeled simply by page number. The essay from which each quotation comes can be viewed in the Works Cited. those who possess them represent the powerful bourgeoisie: "The Three [Rings], fairest of all, the Elf-lords hid from [Sauron], and his hand never touched them or sullied them. Seven the Dwarf-kings possessed, but three he has recovered, and the others the dragons have consumed. Nine he gave to Mortal Men . . . and they became Ringwraiths" (Tolkien 51). ${ }^{2}$ Gandalf, Galadriel, and Elrond possess the Three Rings, and they are three of the most powerful characters in Middle-earth. The nine Ringwraiths of Sauron are the most powerful force to oppose Frodo and the Fellowship in the journey to Mordor. The Rings of Power function in the same way as the wealth that creates the bourgeoisie, and the "One Ring to rule them all" might as well be the capitalist system itself that allows this polarization of power.

In addition to the parallels between the power in a capitalist system and the power of the Ring, there are further connections to draw between Marx's writings and Middle-earth. The Marxist view of the economy is teleological - that is, headed to an ultimate stage of communism, with capitalism being merely a stepping-stone, lamentable but necessary, on the path to economic equality. To this end, Marx urges the proletariat to rise up against the oppressive bourgeoisie, even suggesting that when the development of modern technology and industry empowers the wage-laborer, this uprising becomes unavoidable: "What the bourgeoisie therefore produces, above all, are its own grave-diggers. Its fall and the victory of the proletariat are equally inevitable" (21).

In the same way, the capitalism represented in the Ring must be overthrown by the proletariat - the havenots of Middle-earth, those who do not possess power through the Ring - at the very place of its origin: "Gandalf has to re-emphasize strongly and against opposition in 'The Council of Elrond', the Ring cannot simply be left unused, put aside, thrown away: it has to be destroyed, and the only place where it can be destroyed is the place of its fabrication, Orodruin, the Cracks of Doom" (Shippey 114). Gandalf's view of Middle-earth is, like Marx's, teleological, with the regime of power instituted by the Ring a mere transitional phase that must be destroyed on the way to the idyll. Thus, when

2 This essay includes occasional references to The Silmarillion by Tolkien; however, unless otherwise stated in the parenthetical citation, quotations by Tolkien come from his three-volume The Lord of the Rings. 
the Ring is destroyed, and Sauron, its creator, is destroyed with it, this destruction seems almost inevitable, as if Sauron long ago dug his own grave by forging the Ring at Orodruin. Moreover, this destruction marks the teleological transition from capitalism to communism, in which the Third Age of Middle-earth gives way to the Fourth.

The Fourth Age brings with it the fading of the elves and the increased dominion of men, signifying a shift away from an enchanted, fantastical world; however, the Fourth Age can still be idealized precisely because it begins with the termination of the evil powers that marked the age before it. In the appendix to his work, Tolkien provides a brief glimpse into the earliest years of the Fourth Age, an idealized time in which Sam, who was once merely a gardener and a sidekick (that is, a have-not) is elected mayor seven times. Similarly, Tolkien notes that when Legolas crosses the sea to the Grey Havens, Gimli crosses it with him, the first dwarf ever to do so, and this episode signifies that race and class distinctions have been set-aside in the Fourth Age (109798). In the same way, Marx's hypothetical communist society involves the elevation of the have-nots and the dissolution of class distinction.

Marx concedes that the capitalist system provides extravagance and beauty for the bourgeoisie: "It is true that labour produces for the rich wonderful things - but for the worker it produces privation. It produces palaces - but for the worker, hovels. It produces beauty - but for the worker, deformity" (654). In the same way, Galadriel admits to Frodo that it is her possession of one of the Three Rings that allows her to create the great mystical beauty of Lothlórien: "If you fail, then we are laid bare to the Enemy. Yet if you succeed, then our power is diminished, and Lothlórien will fade, and the tides of Time will sweep it away" (Tolkien 365). Although Marx and Galadriel alike know that the overthrow of bourgeois power is necessary to alleviate the oppression of the have-nots, both also acknowledge the magnificent luxuries born of the capitalist system. Indeed, after Frodo delivers the Ring to Orodruin where it is destroyed, the powerful realm of Sauron falls, but so, too, do the peaceful and magnificent realms of Elrond and Galadriel in Rivendell and Lothlórien. Thus, the powerful elves leave the realm of Middle-earth for the Grey Havens, the era of their power having passed.

It would be a mistake, therefore, to interpret Marx as suggesting that a communist utopia would be any sort of paradise in the traditional sense. On the contrary, he concedes that, with the overthrow of the bourgeoisie, the impressive creative power of capitalism - that which produces "wonderful things" and "palaces" for the upper rung of society - is sacrificed. Landa asserts that Galadriel's message to Frodo echoes this sacrifice: "With the enormous destructive power of the capitalist mode of production, its overwhelming capacity to enslave and cripple, are also gone its enormous productive capacities ... After power has been renounced, the world becomes safe and habitable but also more meagre and mundane; not paradise regained but hell repelled" (128). Even so, both Marx and Galadriel see that the overthrow of their respective enemies, capitalism and the Ring, is well worth the loss of "rich wonderful things," or the fading of the elves.

The proletariat struggle that Marx envisions is further mirrored in the power struggles of Middle-earth during "The Scouring of the Shire," the penultimate chapter of The Lord of the Rings. The evil wizard Saruman, in a last-ditch effort to regain power, conquers the Shire and turns it into a sort of dysfunctional communist society. Here we see the fullest manifestation in Middle-earth of a world without the impressive productive potential of capitalism, the Ring. Upon their return to the Shire, the hobbits find their native land austere, industrialized, and almost unrecognizable: "The pleasant row of old hobbit-holes in the bank on the north side of the Pool were deserted, and ... there was a whole line of the ugly new houses all along Pool Side . . . And looking with dismay up the road towards Bag End they saw tall a chimney of brick in the distance. It was pouring out black smoke into the evening air" (1004). Furthermore, Farmer Cotton tells Merry and Frodo, "The ruffians went round gathering stuff up 'for fair distribution': which meant they got it and we didn't" (Tolkien 1012-3). In other words, the problem of materialism and capitalism throughout the trilogy seems to pave the way for an even more sinister communism toward the very end of the books, for a world without the Ring of power is a world in which Saruman must establish his dominion in ways eerily similar to the communist powers growing in influence at the time Tolkien penned the trilogy.

It is important to note, however, that what occurs in the Shire when the Travellers return-austerity, smokestacks, and pollution-is not communism as Marx grasps it. In fact, once Saruman (who has taken control of the Shire only because he is still greedy for power 
but too weak to achieve it anywhere else) is destroyed, something resembling Marx's true vision of communism seems to establish itself. The hobbits all work together to restore the Shire, not laboring because they have to, but because they want to: "Hobbits can work like bees when the mood and the need comes on them. Now there were thousands of willing hands of all ages" (1022). Working for a shared goal, the hobbits labor voluntarily and enthusiastically, with no apparent hierarchy, and no stronger power to rob them of the fruits of their labor.

Moreover, upon their return to the Shire, Sam remembers his gift from Galadriel, and he scatters the dust of Lothlórien throughout the Shire and plants the golden nut she has given him, not in his private garden, but in the Party Field where all can see and enjoy it. He tells his friends, "I'm sure the Lady would not like me to keep it all for my own garden, now so many folk have suffered" (1022-23). With the destruction of the Ring, the Shire does away not only with any instance of unwilling labor, but also with the hoarding of wealth for one at the expense of many. Rather than hoard his wealth, Sam recognizes that the value of Galadriel's gift - its beauty - is something to be shared by all, equally. With the exception of Frodo (who cannot live contentedly without the Ring and so must depart for the Grey Havens), there seems to be little consequence in the Shire following the destruction of the Ring. In fact, it seems to be an even happier and more productive realm with the darkness of the Third Age gone. In any case, the examples of Lothlórien and Hobbiton both affirm Marx's claim that, regardless of the sacrifices, the world is indisputably better once the evil power of capitalism - the Ring - is done away with.

Perhaps the most significant effect of capital's power in Middle-earth is seen in the greed and materialism fostered by the Rings, forces which Tolkien clearly laments. Marx states, "The only wheels which political economy sets in motion are avarice and the war amongst the avaricious - competition" (652). The alluring power of the Rings inspires greed in the hearts of all in Middle-earth - the evil and the good. Sméagol is driven by greed to murder his only friend Déagol in his greed for the one Ring: "He caught Déagol by the throat and strangled him, because the gold looked so bright and beautiful. Then he put the ring on his finger" (Tolkien 53). This same greed seizes Boromir, one of the trusted members of the Fellowship, and he demands the
Ring from Frodo (397-9). Denethor, Saruman, the orcs, and Sauron himself, of course, are greedy for the Ring. Frodo offers the Ring to Gandalf, and later to Galadriel; both are tempted by greed for power, and both refuse the offer vehemently in the same way: "With that power I should have power too great and terrible" (61). Even for Frodo the ring-bearer, his greed becomes too powerful, and at the cracks of Mount Doom, on the brink of completing his arduous quest, Frodo ultimately fails, telling Sam, "I do not choose now to do what I came to do. I will not do this deed. The Ring is mine!" (945).

Stefan Arvidsson clarifies an essential difference between the Ring in Middle-earth and capital in our society: "Tolkien's rings of power have to do with power for power's own sake ... the struggle is not a battle for wealth through which it is possible to enlist people to serve . . but a more general power struggle. Power becomes immaterial" (10). This distinction is important to make between the real society Marx writes about and the created world of Tolkien. Yet even so, greed for wealth and greed for the power of the Ring manifest themselves in many of the same ways. The effect of the Ring's power is, as Marx predicts about communism, a "war amongst the avaricious" (652).

From capitalism's obsession with property possession comes what Marx calls the "fetishism" of commodities, that is, the assumption that when two individuals interact, their commodities interact as well. The result of fetishism is "the conversion of men into producers of commodities" (669), such that "the labourer is nothing else, his whole life through, than labour-power, that therefore all his disposable time is by nature and law labour-time, to be devoted to the self-expansion of capital" (671). In a society that prizes material wealth and production, the individual becomes defined solely by his relationship to production.

The plague of greed in Middle-earth is the result of this fetishism of commodities, with the one Ring representing the "quintessential commodity" (Landa 123). According to Marx, this fetishism occurs specifically when, in the act of exchange, a commodity is conflated with those individuals involved in the exchange: "Whenever, by an exchange, we equate as values our different products, by that very act, we also equate, as human labour, the different kinds of labour expended upon them" (666). In the labor of creating the one Ring, Sauron becomes simultaneously its master and its slave, unable to exercise his power - or even to exist — without 
it. Sauron's existence becomes defined by his labor and the commodity he creates, and he exchanges his autonomy for a material product. In the same way, Bilbo's surrender of the Ring to Gandalf and Frodo represents an exchange of value. Like Sauron, Bilbo exchanges his autonomy for the tempting power of the Ring as a commodity, and this makes him into something he is not-a creature eerily similar to Gollum. Bilbo tells Gandalf, "You won't get it. I won't give my Precious away" (Tolkien 34). Ultimately, however, Bilbo does surrender the Ring, and although he lives the rest of his life wondering after the Ring, he is no longer its slave.

The exchange between Bilbo and Gandalf in which the hobbit willingly surrenders the wealth of the Ring shows a triumph of the individual self over the quintessential commodity. Frodo, on the other hand, becomes too attached to the Ring, and at the very completion of his quest, Frodo abandons his mission and claims the Ring for his own (Tolkien 945). In truth, however, this exchange represents not Frodo's possession of the Ring but the Ring's possession of Frodo: he willingly surrenders as its slave, exchanging his autonomy for the fetishized commodity. The result is that Frodo lives on in a sort of half-life, eventually giving up his life in the Shire to join Galadriel, Elrond, Gandalf, and Bilbo in their journey to the Grey Havens. This is because "Frodo is unable to live in a world where he cannot have the Ring - his 'Precious' - and so he has to eventually leave; he craves what he cannot have, and cannot live in peace without it: this, arguably, is an appropriate definition of greed" (Larimore 69). Whether for Frodo or a bourgeois capitalist, the exchange of one's autonomy for wealth or power is the result of the fetishism of commodities, which is, in turn, the direct result of greed.

By concentrating the fetishized commodity more or less into a single object, Tolkien raises the important question of whether greed exists inherently in the individual or as an outside force. In a Marxist response to this question, we must turn to Marx's notion of historical materialism - the idea that "life is not determined by consciousness, but consciousness by life" (Marx and Engels 656). Therefore, it is likely that Marx would read the avarice in Middle-earth as the result of external forces and circumstances. Of course, it is true that some races of Middle-earth are more prone to greed than others, most notably, the dwarves, who are producers and hoarders of wealth. This is especially apparent in Tolkien's first Middle-earth work, The Hobbit, in which the thirteen dwarves who accompany Bilbo, led by Thorin Oakenshield, are driven forward in their quest exclusively by greed, to retrieve the treasure taken from them by Smaug. It is interesting to note, however, that the Middle-earth race best known for its greed proves to be the most incorruptible in the face of Sauron's dark power, for Tolkien writes, regarding the Seven Rings Sauron gave to the dwarves, "The Dwarves indeed proved tough and hard to tame; they ill endure the domination of others, and the thoughts of their hearts are hard to fathom, nor can they be turned to shadows" (Silmarillion 345-46). In the end, it is men, not dwarves, who are most easily ensnared by Sauron's wickedness and the greed for power.

The fact that one race of Middle-earth is, by nature, more avaricious than the rest seems to contradict Marx's notion of historical materialism, which favors nurture over nature. However, Tolkien does go on to say that the dwarves "used their rings only for the getting of wealth" (Silmarillion 346). In other words, the possession of material wealth and power only makes them greedy for more. With this in mind, Middle-earth does seem consistent with Marx, who would argue that greed is brought on by outside forces. In both our real society and Middle-earth, in the same way that consciousness is determined by life, the potency of greed is determined by possession, by the presence of something for which to be greedy.

Marx portrays the capitalist system to be one in which production and material wealth are the ultimate and only concerns, to the detriment of man's humanity and individuality. In a capitalist system, Marx states that, because of the virtual enslavement of the laborer to production, "What is animal becomes human and what is human becomes animal" (655). Tolkien exemplifies this exchange in Middle-earth through Sauron, the creator and producer of the One Ring. While Sauron's ambitions are always nefarious, it is the action of producing the Ring that initially dehumanizes (or devalarizes) him: "Secretly Sauron made One Ring to rule all the others, and their power was bound up with it . . . And much of the strength and will of Sauron passed into that One Ring" (Tolkien, Silmarillion 344). Sauron must sacrifice a significant part of himself to produce the material source of power, exchanging any sense of humanity for power, production, and commodity.

Perhaps no character in The Lord of the Rings represents this dehumanization better than Gollum, who, by 
his greed for the Ring, is transformed from a hobbit to a grotesque beast that feasts on raw fish and fears the light of the sun. Even the kind and generous hobbit Bilbo shows signs of animalistic corruption after his extended possession of the Ring: "Bilbo put out his hand. But Frodo quickly drew back the Ring. To his distress and amazement he found that he was no longer looking at Bilbo; a shadow seemed to have fallen between them, and through it he found himself eyeing a little wrinkled creature with a hungry face and bony groping hands" (Tolkien 232). Because Gollum possessed the Ring for 478 years before he lost it to Bilbo, whereas Bilbo possessed it for only 60 years before surrendering it to Frodo, the effects of Bilbo's greed and possessiveness are not as pronounced. Even so, it is likely that Bilbo would have grown to resemble Gollum had he kept the Ring longer.

As the Ring becomes greater, Gollum and Bilbo (and everyone else in Middle-earth) become less. According to Marx, "With the increasing value of the world of things proceeds in direct proportion the devaluation of the world of men ... The worker puts his life into the object; but now his life no longer belongs to him but to the object" (653). By contrast, the hobbits of the Shire, who are (until the trilogy commences) free from the influence of any of the Rings of power, "[a]re simple, peaceful, content with their lot, and (most importantly) generous; for example, when it comes to a hobbit's birthday, it is the one whose birthday it is who gives presents to their party guests, not receiving any!" (Larimore 65). It is important to note that, in the question raised by Tolkien of whether greed is inherent to the individual or the result of outside forces, the hobbits are again consistent with Marx's notions of historical materialism. Although the hobbits (and all races of Middle-earth) show themselves to be corruptible, they are not, by nature, corrupt, for Tolkien presents in the hobbits a people generally free of greed and materialism until tempted by an external force, by something for which to be greedy. Admittedly, like the dwarves, Frodo seems to be more prone to greed than his uncle Bilbo; however, what is most important to note is that neither hobbit is exceptionally greedy until the Ring enters his life (that is, until the circumstances of his life determine his consciousness). Additionally, this is consistent with Marx's assertion that the devaluation of men is directly proportional to the increased valuation of things: the world of men is devaluable, but not, by nature, devalued.
Greed not only dehumanizes any who seek the power of the Ring; it also leads to their demise and downfall. Gollum, for example, loses his life as the direct result of his avarice: "This pursuit of material wealth ultimately brings about his (timely) downfall in the fires of Mount Doom" (Larimore 69). Gollum's desperation to acquire the Ring, his "precious," is so great that he pounces on Frodo to bite off his finger, knowing full well that a pit of lava awaits him below. A despicable and pitiful wretch, Gollum is well on his way to becoming a Ringwraith, like the nine men who possessed nine of the original rings - the Nazgûl. Gandalf explains to Frodo that a Ringwraith "does not die, but he does not grow or obtain more life, he merely continues, until at last every minute is a weariness. And if he often uses the Ring to make himself invisible, he fades: he becomes in the end invisible permanently, and walks in the twilight under the eye of the Dark Power that rules the Rings" (Tolkien 47).

The wraithing of the nine power-hungry men-and almost of Gollum and Frodo-is a severe example of the result of greed and the fetishism of commodities. As Jeffers explains, "They are defined by the goods they have been given and as objects that use those goods. The result is total domination of the person by Sauron" (11). The identity of the Ringwraiths is defined, even in their very title, by their relationship to the Ring. They serve only to help their master accumulate power and expand his realm, no matter the cost to hobbits and elves and Ents and all the creatures of Middle-earth. In the same way that the bourgeoisie "has converted the physician, the lawyer, the priest, the poet, the man of science, into its paid wage-labourers" (Marx and Engels 16), the Ring has converted the great lords of Númenor, great warriors, sorcerers, and kings, into the Nazgûlmere shadows of their former selves and laborers for the will of Sauron and the Ring. In addition to the lords of Númenor, Higham lists the casualties in the plague of avarice in Middle-earth: Thorin Oakenshield in The Hobbit, who lusts after the Arkenstone and is killed; the dwarves who mine mithril, or silver, and in so doing, disturb the Balrog of Moria, which kills their king; Saruman, who seeks to control the lands of Orthanc and fades away into nothing in his death; and Sauron, who seeks greedily to control all of Middle-earth, and who falls in the process when the Ring is destroyed (151).

These examples of greed highlight two important clarifications: first, it is not only the isolated incident of 
the Ring that catalyzes greed and its corresponding destructiveness in Middle-earth. Characters are greedy for many things, both physical and abstract, but the Ring serves as the most prominent example, distinct in that it functions as an active force, consciously spurring its possessors on toward greater avarice, greater self-destruction, and greater subservience to the Ring. In Marxist terms, members of a capitalist society are greedy for many things, material and immaterial, with capitalism's promise of prosperity being merely the most prominent source for greed.

Second, the fact that not only the exceptionally evil characters of Middle-earth fall to the power of the Ring, but also the good characters, is a testament to a central claim in both Marx and Tolkien: anyone is susceptible to greed, to the effects of fetishizing commodities, and to the evils of material possessiveness. Clark and Timmons articulate a common theory that each of the races of Middle-earth is representative of one of the Seven Deadly Sins (as they are represented in medieval literature): "Dwarves-Greed, Men-Pride, Elves-Envy, Ents-Sloth, Hobbits-Gluttony, Wormtongue-Lechery, and Orcs-Anger" (84). Yet there are exceptions to this strict - and, in light of Tolkien's authorship, dangerously allegorical - reading. For example, in The Hobbit, the leader of the dwarves "Thorin Oakenshield ... [admits] that happiness is where there is an absence of greed and materialism" (Larimore 64). Similarly, in The Lord of the Rings, Aragorn, a man, sheds his pride to help the lowly hobbits in their quest; the Ents shed their laziness to rise up against Saruman at Isengard and bring down his stronghold; and Sam sheds his gluttony to share the last bit of lembas bread with Frodo in Mordor.

Larimore makes a much more apt observation, and one that Marx himself would likely agree with: Tolkien's message teaches readers today that the pursuit of wealth, power, and greed turns society into Gollum (70). There is a Gollum in everyone, for greed and avarice have the power to corrupt universally. Gollum himself started out as the hobbit Sméagol- that is, he was not corrupt by nature, but he was very corruptible in the presence of something for which to be greedy. Put another way, an "indication of this depoliticization in the work of Tolkien is the fact that in Tolkien power is an instrument that corrupts anyone to whom it comes, irrespective of motive and interests" (Arvidsson 13). For this reason, Bilbo's face becomes unrecognizable; the lords of Númenor become Ringwraiths; Frodo himself begins to wraith; Boromir threatens the life of the ring-bearer in the Fellowship; and Gandalf and Galadriel both wisely shy away from the power of the Ring. All of these examples, at least at the outset, involve benign characters; yet Gandalf is right to "[insist] that the Ring is deadly dangerous to all its possessors: it will take them over, 'devour' them, 'possess' them" (Shippey 114, emphasis mine).

Ultimately, the power of the Ring to universally destroy its possessors must be tied back to the discussion of Marxism and capitalism. According to Marx's theory of historical materialism, "Men, developing their material production and their material intercourse, alter, along with this their real existence, their thinking and the products of their thinking" (Marx and Engels 656). Material production in the Third Age of Middle-earth takes shape most obviously as the One Ring, and at the very moment that Sauron forges the Ring, all of the races of Middle-earth must reorient their thinking exclusively through the lens of the Ring and their varying degrees of subjectivity to it. In the same way, Marx would say one's consciousness is determined either as a member of the bourgeoisie or proletariat, and as a product of one's circumstances. Landa explains, "In the Ring are congested all the immeasurable contradictions of the capitalist system: the enormous productivity with the annihilating destructiveness, the unlimited power of the few with the utter impotence of the many, the extravagant luxury and the epidemic poverty, the sanguine promise with its horrible betrayal" (122).

Ultimately, it is the way one thinks of the Ring that determines his or her consciousness. Characters like Gandalf, Aragorn, Legolas, Gimli, Sam, and Treebeard are free to think broadly of saving Middle-earth, but this is only because their collective consciousness is not determined by greed for the Ring. These characters embody the opposite of Marx's warnings, for in each hero, what is human remains human (or elf, or dwarf, or Ent), and what is animal remains animal, enabling all of these characters to maintain their autonomy and humanity. Of course, these characters are not immune to the temptation of the Ring's power. However, recognizing the importance of destroying Sauron, they triumphantly resist the temptation to possess it - unlike Boromir, Saruman, Gollum, or Frodo, to name only a few. In the same way, "(i)n choosing the route of having Bilbo give up the Ring of his own free will, Tolkien presents a character who is the embodiment of hope for the world, someone that 
is not overcome by greed and lust for great wealth and dominance" (Larimore 66). Although Tolkien did not deliberately write his Middle-earth chronicles with any sort of allegory in mind, the characteristics and effects of the Ring very closely resemble those of capitalism as Marx sees it. The most despicable and malicious embodiments of evil in Middle-earth are those driven by greed for power and material possessions, and this serves, through a Marxist lens, as a necessary critique (albeit unintentional by the author) of capitalism. The forces of the greatest good, on the other hand, are those that resist greed in spite of temptation, whose consciousness is free of avarice and greed.

\section{Works Cited}

Arvidsson, Stefan. "Greed and the Nature of Evil: Tolkien Versus Wagner." Journal of Religion and Popular Culture, vol. 22, no. 2, 2010, pp. 2-21. University of Toronto Press, doi: http://dx.doi.org/10.3138/jrpc.22.2.007.

Cain, William E., et al., eds. The Norton Anthology of Theory and Criticism, vol. 2, Norton, 2010.

Clark, George, and Daniel Timmons. J. R. R. Tolkien and His Literary Resonances:Views of Middle-earth. Greenwood P., 2000.

Freedman, Carl. "A Note on Marxism and Fantasy." Historical Materialism, vol. 10, no. 4, 2002, pp. 261271. Booksandjournals.brillonline.com/docserver/ $14654466 /$ v10n4_s $12 . p d f$ ? expires $=147822$ $3387 \&$ id $=i d \& a c c n a m e=a b i l e n e t x \& c h e c k-$ sum=AD0884970B325DC50E97F0F77A29485A.

Higham, Steve. "Ideology in The Lord of the Rings: A Marxist Analysis." University of Sunderland, 2012, pp. 1-255. Sure.sunderland.ac.uk/3552/.

Jeffers, Gregory C. "Oppression and Resistance: Socialist Theory and Christianity in The Lord of the Rings." Conversations, vol. 1, no.1, 2013, pp. 1-14. O j s . acu.edu/ojs/index.php/conversations/article/view/9.

Landa, Ishay. "Slaves of the Ring: Tolkien's Political Unconscious." Historical Materialism, vol. 10, no. 4, 2002, pp. 113-133. Academic Search Complete, ezproxy.acu.edu:2048/login?url=http:// search.ebscohost.com/login.aspx?direct=true\&d$\mathrm{b}=\mathrm{a} 9 \mathrm{~h} \& \mathrm{AN}=9555846 \&$ site $=$ ehost-live $\&$ scope $=$ site.

Larimore, Christopher. "The Problem of Greed in JRR Tolkien's The Hobbit and The Lord of the Rings." Plaza: Dialogues in Language and Literature, vol. 2, no. 2, 2012, pp. 64-70. Journals.tdl.org/plaza/index.php/plaza/article/view/6318.
"The Letters of J. R. R. Tolkien." Edited by Humphrey Carpenter, Houghton Mifflin, 1981.

Marx, Karl, and Friedrich Engels. "Capital, Volume 1." Cain, et al., pp. 663-74.

---. "Economic and Philosophic Manuscripts of 1844." Cain, et al., pp. 651-5.

---. "The German Ideology." Cain, et al., pp. 655-6.

---. "Grundrisse." Cain, et al., pp. 661-2.

---. Manifesto of the Communist Party. Marxists Internet Archive, translated by Samuel Moore, 1848, www. marxists.org/archive/marx/works/download/pdf/ Manifesto.pdf.

---. "Preface to A Contribution to the Critique of Political Economy." Cain, et al., pp. 662-3.

Nebauer, John. "Tolkien's 'Feudal Socialism."” Green Left Weekly, 12 Dec. 2001, www.greenleft.org.au/content/ tolkiens-feudal-socialism. Accessed 18 Apr. 2016.

Shippey, Tom. J. R. R. Tolkien: Author of the Century. HarperCollins, 2000. Theology, Philosophy and Science.

"JRR Tolkien: The Free Market Capitalist." Youtube, 26 Dec. 2015, www.youtube.com/watch?v=XzB36JNk03s. Accessed 21 Apr. 2016.

Tolkien, J. R. R. The Lord of the Rings. HarperCollins, 2007.

Tolkien, J. R. R. The Silmarillion. Edited by Christopher Tolkien, HarperCollins, 2013. 